\title{
Does it pay to work from home? Examining the factors influencing working from home in the Greater Dublin Area
}

\begin{abstract}
Encouraging working from home or telecommuting has long been seen as a means to encourage sustainable mobility. With increase coverage of high-speed Internet access and escalating transport costs, telecommuting has become more attractive than ever. This paper seeks to explore the factors that encourage telecommuting in the Greater Dublin Area (GDA) in Ireland. The research presented in this paper considers how factors such as public transport access, deprivation, industrial grouping, car ownership, household structure and residential density, impact upon the decision to work from home. The paper also seeks to determine the cost savings in terms of travel time saved that those telecommuting enjoy on an annual basis. The findings of this study show a substantial travel time and cost of travel time saving in the GDA. The findings also suggest areas several factors such as broadband Internet coverage, public transport availability and occupation all impact upon the propensity to work from home.
\end{abstract}

\section{Introduction and background}

This paper focuses upon the GDA and asks the question what factors impact upon individuals' decision to working from home. The GDA includes the counties of Dublin, Kildare, Wicklow and Meath and in 2011 had a population of approximately 1.8 million (CSO, 2011). Typically approximately $56 \%$ of the total population of the GDA drive to work alone on a daily basis (See Table 2) and car ownership levels in some areas of Dublin County are substantially higher than that of the rest of Ireland (Caulfield, 2012). Over the past number of years policies have been introduced to reduce reliance on driving and encourage modal shift to more sustainable modes of transport. In 2009, the Irish government launched a sustainable travel plan that aimed to reduce car commuting by $20 \%$ (Department of Transport, 2009). Some success has been achieved in this area with an increase in cycling in the Dublin but with limited success outside of Dublin (Caulfield, 2014). However, the GDA has a number of problems that were the product of the recent housing boom and as a result the newer housing stock in the GDA tends to have poor public transport access and residents have longer commuting times (Caulfield and Ahern, 2014).

Telecommuting or working from home has been a policy that has been mostly overlooked in Ireland. Given the nature of the low density housing stock in Dublin and the extensive costs in constructing large scale large new public transport systems in the GDA (Caulfield et al, 2013); the research presented in this paper seeks to determine what benefits a policy of working from home could have in the GDA. The research presented in this paper demonstrates the rates of working from home in the GDA and the travel time saved and economic benefits of working from home.

This section of the paper examines the current rates of telecommuting in the GDA. Table 1 contains a break down of each of the modes of transport used to travel to work in the GDA. The first four areas detailed in the table relate to county Dublin. It can be seen in these areas that the percentage of those working from home varies with Dún Laoghaire-Rathdown having the highest percentage of individuals working 
from home. The results from the counties surrounding Dublin County (those that make up the rest of the GDA) show a higher percentage of working from home with Wicklow having the highest overall percentage. Figure 1 maps the percentages of those working from home in the GDA and is segmented into electoral districts. The map shows that it is the areas in the south of the GDA that have the highest percentages of individuals working from home. To provide further context involving the rates of working from home, Figure 2 provides the percentages of those indicating they work from home from the past three sets of Census data in Ireland. The results show that over the past three Census time periods the rates have fluctuated with the percentages in 2011 being lower than those for 2006, with the exception of County Wicklow. Overall the trend between 2006 and 2011 shows a decline in the numbers working from home. This can be attributed to the increase in unemployment in Ireland during this time period of 10.3\% between 2006 and 2011 (CSO, 2015).

Table 1 Means of travel to work in the GDA

\begin{tabular}{|c|c|c|c|c|c|c|c|c|}
\hline \multirow[t]{2}{*}{$\begin{array}{l}\text { Mode of } \\
\text { Transport }\end{array}$} & \multicolumn{2}{|c|}{ Dublin City } & \multicolumn{2}{|c|}{ South Dublin } & \multicolumn{2}{|l|}{ Fingal } & \multicolumn{2}{|c|}{$\begin{array}{l}\text { Dún Laoghaire- } \\
\text { Rathdown }\end{array}$} \\
\hline & $\mathbf{N}$ & $\%$ & $\mathbf{N}$ & $\%$ & $\mathbf{N}$ & $\%$ & $\mathbf{N}$ & $\%$ \\
\hline Walk & 47,028 & 22.4 & 6,535 & 6.4 & 7,279 & 6.4 & 6,838 & 8.1 \\
\hline Cycle & 16,960 & 8.1 & 3,287 & 3.2 & 2,401 & 2.1 & 4,022 & 4.8 \\
\hline Bus & 35,500 & 16.9 & 12,227 & 11.9 & 11,110 & 9.7 & 6,706 & 7.9 \\
\hline Rail & 14,738 & 7.0 & 2,476 & 2.4 & 11,1163 & 9.7 & 11,340 & 13.4 \\
\hline Motorcycle & 1,786 & 0.9 & 1,166 & 1.1 & 975 & 0.9 & 863 & 1.0 \\
\hline Drive (alone) & 78,582 & 37.4 & 65,991 & 64.1 & 69,469 & 60.6 & 46,789 & 55.4 \\
\hline $\begin{array}{l}\text { Drive } \\
\text { (Passenger) }\end{array}$ & 5,618 & 2.7 & 4,039 & 3.9 & 4,423 & 3.9 & 2,146 & 2.5 \\
\hline Van & 5,106 & 2.4 & 5,042 & 4.9 & 4,724 & 4.1 & 2,168 & 2.6 \\
\hline Other & 385 & 0.2 & 289 & 0.3 & 412 & 0.4 & 195 & 0.2 \\
\hline $\begin{array}{l}\text { Work from } \\
\text { home }\end{array}$ & 4,316 & 2.1 & 1,741 & 1.7 & 2,609 & 2.3 & 3,346 & 4.0 \\
\hline Total & 210,019 & 100.0 & 102,763 & 100.0 & 114,565 & 100.0 & 84,413 & 100.0 \\
\hline \multirow{2}{*}{$\begin{array}{l}\text { Mode of } \\
\text { Transport }\end{array}$} & \multicolumn{2}{|l|}{ Kildare } & \multicolumn{2}{|l|}{ Meath } & \multicolumn{2}{|c|}{ Wicklow } & \multicolumn{2}{|c|}{ Total GDA } \\
\hline & $\mathbf{N}$ & $\%$ & $\mathbf{N}$ & $\%$ & \begin{tabular}{l|}
$\mathbf{N}$ \\
\end{tabular} & $\%$ & $\mathbf{N}$ & $\%$ \\
\hline Walk & 5,837 & 7.0 & 4,455 & 6.6 & 3,914 & 3.0 & 81,886 & 11.5 \\
\hline Cycle & 1,009 & 1.2 & 439 & 0.7 & 426 & 0.8 & 28,544 & 4.0 \\
\hline Bus & 3,241 & 3.9 & 3,156 & 4.7 & 1,966 & 3.9 & 73,906 & 10.4 \\
\hline Rail & 4,220 & 5.1 & 1,195 & 1.8 & 2,790 & 5.5 & 147,922 & 20.7 \\
\hline Motorcycle & 444 & 0.5 & 315 & 0.5 & 282 & 0.6 & 5,831 & 0.8 \\
\hline Drive (alone) & 56,065 & 67.5 & 49,944 & 74.0 & 32,621 & 64.2 & 399,461 & 56.0 \\
\hline $\begin{array}{l}\text { Drive } \\
\text { (Passenger) }\end{array}$ & 3,170 & 3.8 & 2,798 & 4.1 & 1,913 & 3.8 & 24,107 & 3.4 \\
\hline Van & 5,369 & 6.5 & 5,748 & 8.5 & 3,430 & 6.8 & 31,587 & 4.4 \\
\hline Other & 711 & 0.9 & 762 & 1.1 & 502 & 1.0 & 3,256 & 0.5 \\
\hline $\begin{array}{l}\text { Work from } \\
\text { home }\end{array}$ & 3,005 & 3.6 & 3,169 & 4.7 & 2,934 & 5.8 & 21,120 & 3.0 \\
\hline Total & 83,071 & 100.0 & 67,526 & 100.0 & 50,778 & 100.0 & 713,135 & 100.0 \\
\hline
\end{tabular}




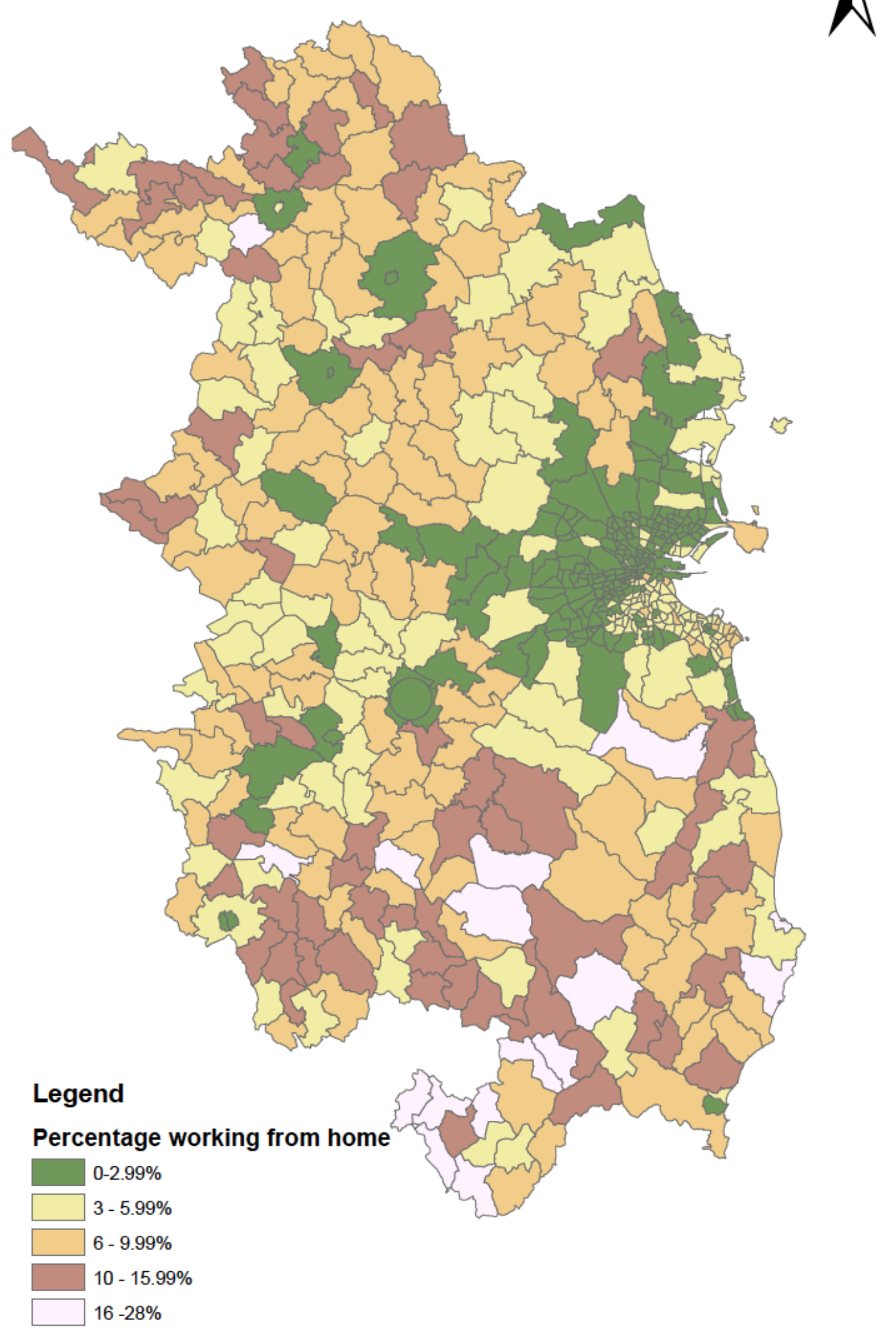

Figure 1 Percentages of those working from home 


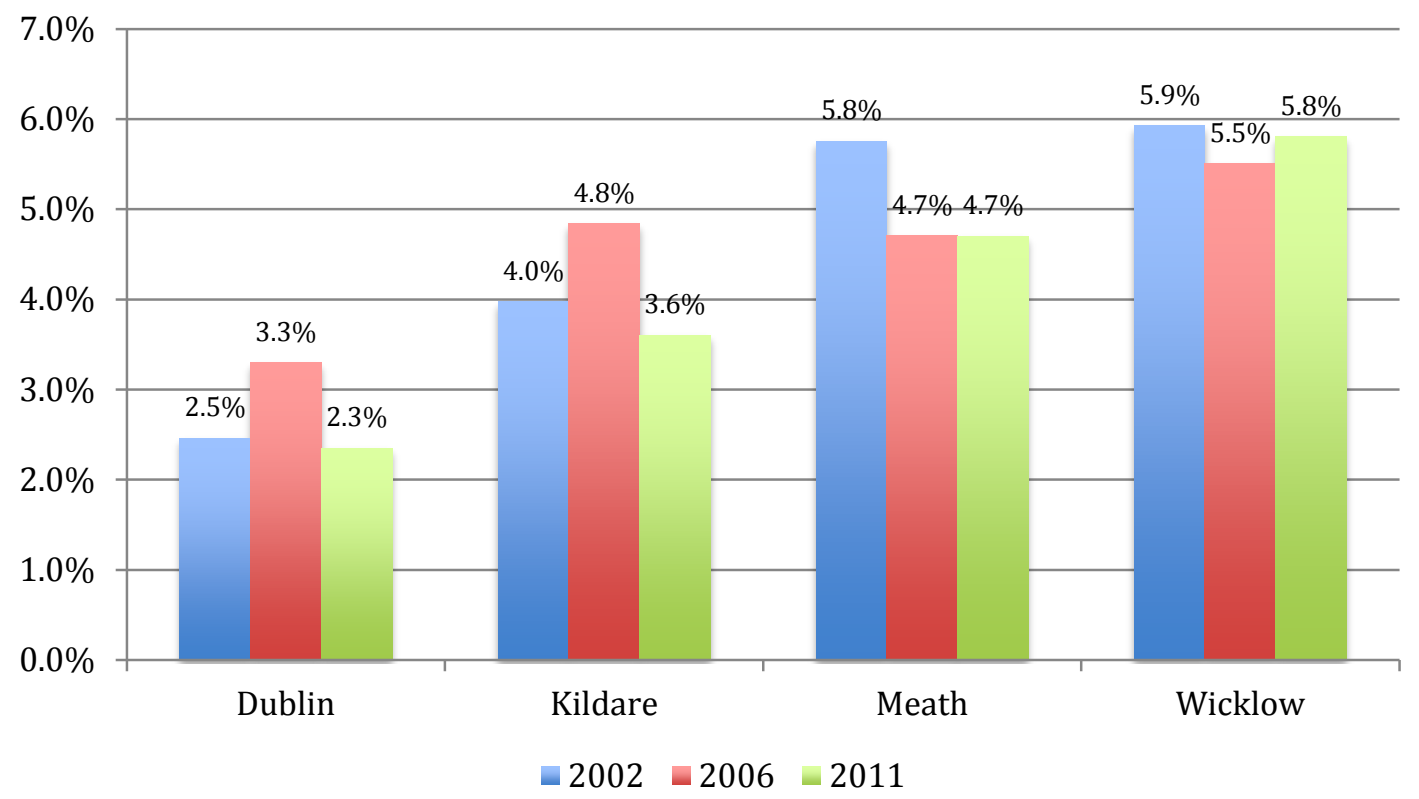

Figure 2 Percentages of individuals working from home 2002-2011

Table 2 presents the demographics of those working from home in the GDA and compares them to the population in the GDA. The first set of results relate to gender, they show that a higher percentage of males work from home. The findings for the age categories shows that a higher percentage of those over the age of 45 were said to be working from home. The industrial group that the individual belonged to also examined in this research to attempt to identify which workers are most likely to be in a position to be able to work from home, for ease of reference these groups are numbered as shown in Table 2. The results in Table 2 show that a higher percentage those working in Group 2 were shown to work from home, as one would expect. A greater percentage of those working in Group 6 were shown to work from home. The next set of results relates to education level. The results show little variation between those that completed the different stages of education and working from home. Finally, household composition was examined and it was shown that a greater percentage of those living in households that were a couple with a resident child under or over the age of 19 were working from home. 
Table 2 Demographics of those working from home in the GDA

\begin{tabular}{|c|c|c|c|c|c|c|}
\hline & & \multicolumn{2}{|c|}{$\begin{array}{l}\text { Working from } \\
\text { home }\end{array}$} & \multicolumn{2}{|c|}{ Population } & \multirow[t]{2}{*}{$\begin{array}{l}\% \\
\text { difference }\end{array}$} \\
\hline & & $\mathrm{N}$ & $\%$ & $\mathrm{~N}$ & $\%$ & \\
\hline \multirow[t]{3}{*}{ Gender } & Female & 8,487 & 40 & 354,722 & 48 & -8 \\
\hline & Male & 12,633 & 60 & 382,218 & 52 & +8 \\
\hline & Total & 21,120 & 100 & 736,940 & 100 & \\
\hline \multirow{7}{*}{ Age } & $15-24$ & 439 & 2 & 55,877 & 8 & -6 \\
\hline & $25-34$ & 2,512 & 12 & 239,168 & 32 & -20 \\
\hline & $35-44$ & 5,604 & 27 & 195,468 & 27 & - \\
\hline & $45-54$ & 5,870 & 28 & 148,892 & 20 & +8 \\
\hline & $55-64$ & 4,714 & 22 & 83,628 & 11 & +11 \\
\hline & $65+$ & 1,981 & 9 & 13,907 & 2 & +7 \\
\hline & Total & 21,120 & 100 & 736,940 & 100 & \\
\hline \multirow{10}{*}{$\begin{array}{l}\text { Industrial } \\
\text { Group }\end{array}$} & Group 1: Not stated & 1,719 & 8 & 36,117 & 5 & +3 \\
\hline & Group 2: Agriculture, forestry and fishing & 3,310 & 16 & 10,774 & 1 & +15 \\
\hline & $\begin{array}{l}\text { Group 3: Manufacturing, mining and } \\
\text { quarrying, Electricity, Gas, Water supply and } \\
\text { Waste Management }\end{array}$ & 1,425 & 7 & 63,374 & 9 & -2 \\
\hline & Group 4: Construction & 667 & 3 & 30,137 & 4 & -1 \\
\hline & $\begin{array}{l}\text { Group 5: Wholesale, Retail Trade, } \\
\text { Transportation and Storage, Accommodation } \\
\text { and Food Service Activities }\end{array}$ & 3,013 & 14 & 184,745 & 25 & -11 \\
\hline & $\begin{array}{l}\text { Group 6: Information and Communication, } \\
\text { Financial, Real Estate, Professional, } \\
\text { administration and support service activities }\end{array}$ & 6,840 & 32 & 186,058 & 25 & +7 \\
\hline & $\begin{array}{l}\text { Group 7: Public Administration and Defense; } \\
\text { Compulsory Social Security }\end{array}$ & 315 & 1 & 48,614 & 7 & -6 \\
\hline & $\begin{array}{l}\text { Group 8: Education, Human Health and } \\
\text { Social Work Activities }\end{array}$ & 2,037 & 10 & 144,619 & 20 & -10 \\
\hline & Group 9: Other Service Activities & 1,794 & 8 & 32,502 & 4 & +4 \\
\hline & Total & 21,120 & 100 & 736,940 & 100 & \\
\hline \multirow{4}{*}{$\begin{array}{l}\text { Education } \\
\text { level }\end{array}$} & Not stated & 327 & 1 & 22,263 & 3 & -2 \\
\hline & Completed Second level (High school) & 11,572 & 55 & 412,319 & 56 & -1 \\
\hline & Completed Third level (University Degree) & 9,221 & 44 & 302,358 & 41 & +3 \\
\hline & Total & 21,120 & 100 & 736,940 & 100 & \\
\hline \multirow{9}{*}{$\begin{array}{l}\text { Household } \\
\text { composition }\end{array}$} & Single Person & 1,932 & 9 & 66,507 & 9 & - \\
\hline & $\begin{array}{l}\text { Lone parent: with at least one resident child } \\
\text { aged } 19 \text { or under }\end{array}$ & 455 & 2 & 33,910 & 5 & -3 \\
\hline & $\begin{array}{l}\text { Lone parent: with resident children but none } \\
\text { aged under } 19\end{array}$ & 676 & 3 & 27,082 & 4 & -1 \\
\hline & $\begin{array}{l}\text { Couple: with at least one resident child aged } \\
19 \text { or under }\end{array}$ & 8,374 & 40 & 268,956 & 36 & +4 \\
\hline & $\begin{array}{l}\text { Couple with resident children but none aged } \\
19 \text { or under }\end{array}$ & 2,963 & 14 & 79,217 & 11 & +3 \\
\hline & Couple with no resident children & 4,413 & 21 & 135,559 & 18 & +3 \\
\hline & Other Households & 1,914 & 9 & 106,983 & 15 & -6 \\
\hline & Unknown & 393 & 2 & 18,726 & 3 & -1 \\
\hline & Total & 21,120 & 100 & 736,940 & 100 & \\
\hline
\end{tabular}




\section{Literature Review}

The research conducted to date on telecommuting has tended to focus upon its impacts on urban form and the potential benefits and costs of telecommuting. Several authors postulate that increases in telecommuting can have varying impacts upon urban form.

Several authors have demonstrated the environmental benefits of telecommuting. Schwanen et al (2011) acknowledge that improvements in technology such as video conferencing, has made the option of telecommuting much more convenient. Henderson and Mokhtarian (1996) conducted pioneering work in this area, measuring the environmental benefits of telecommuting in the Puget Sound region and demonstrated substantial environmental benefits. Mokhtarian and Varma (1998) also found similar reductions in emissions with up to a $21 \%$ reduction in carbon dioxide emissions in the study undertaken. Other studies have sought to examine the impacts of telecommuting in relation to distance-travelled reductions. Choo et al (2006) demonstrate that while the distance travelled reductions related to telecommuting in the United States are modest, they can be in some cases be comparable to public transport ridership and as such present a cost efficient means to reduce overall distance travelled. Other studies have examined the potential of telecommuting as a means to reduce energy consumption, in terms of transportation energy, and have shown the ability of this policy to reduce overall energy consumption in the transport sector (Fu et al, 2012; Noland et al, 2006).

A key factor in examining the success of telecommuting or working from home is the frequency of which individuals engage in this activity. Several studies have examined the frequency of telecommuting and what factors impact on the success of these schemes (Nelson et al 2007; Mannering and Mokhtarian, 1995; Olszewski and Mokhtarian, 1994). While other studies have shown how incentives can work to encourage individuals to work from home, the frequency of working from home is not examined in the study presented in this paper as only those that work from home on a regular basis are examined.

One of the research questions considered in this paper is how access to technology impacts upon the likelihood that someone will work from home. The impacts that information and communications technology (ICT) would have on transportation patterns have been discussed extensively and Golob and Regan (2001) were stern in their view that the advent of ICT was the single biggest revolution to hit the transport sector since the automobile. Therefore it is unsurprising how many studies have sought to determine the relationships between ICT usage and telecommuting and how this is changing our travel patterns (Ren and Kwan, 2009; Calderwood and Freathy, 2014). Alexander et al (2010) found that usage of ICT had a greater impact upon the decision to have a more flexible working schedule than traditional socio-economic factors. This concept is further explored by Alexander and Dijst (2012) as they postulate that profession has a large impact upon the ability to have flexible working arrangements and work at least one day of the week from home. The research presented in this paper presents a case study of working from home in the GDA

\section{Methodology and Data}

\subsection{Data}


The main research question of this case study was to ascertain what factors impact upon individuals' decision to work from home. The methods described in this section provide an overview of methods used to achieve this aim.

The data used in this study comes from the 2011 census of Ireland. This dataset is called Place of Work, School or College - Census of Anonymised Records or POWSCAR (CSO, 2011). The 2011 census was conducted on the night of the $10^{\text {th }}$ April 2011. The POWSCAR dataset contains data on almost 2.8 million people and if they were in education or employment how they travelled to their place of education or employment in Ireland. The analysis presented in this paper focuses on the over 700,000 individuals that live and work in the GDA (See Table 2). This data was taken from the POWSCAR dataset and represents all of those that lived and worked in the GDA in 2011.

The definition of someone that works from home in the Census form is when an individual "Works mainly at home of from home" (CSO, 2011). This definition does also include those that work in the agricultural industry. However, this industry accounts for $16 \%$ of the total sample examined (See Table 2). The variables taken from the POWCAR dataset are described in Table 3.

The POWCAR dataset was supplemented with a number of other data sources to determine what factors impact upon the rates of working from home in the GDA. This was conducted, as the POWCAR data doesn't contain information on a number of characteristics considered to be important in the probability that an individual would work from home. Each of these variables are related to the areas and not to the households specifically. Meaning that for example while a household is in an area with for example with a high concentration of broadband Internet coverage, it doesn't mean that this household has a broadband Internet connection. In other words these variables are used as a proxy to measure phenomenon such as the chances of a household having a broadband connection as the specific household data is not available.

The first set of variables relates to deprivation. This measure of deprivation uses a number of demographic, social class and labour market factors to estimate the relative deprivation of an area (Haase and Pratschke, 2012). In the case of study presented in this paper 690 electoral districts are used as the areas. Appendix A has a description of the variables used to estimate the deprivation index. In the study area the deprivation score takes values ranging from -28 (most deprived areas) to 3 (least deprived areas).

Proximity to public transport is also examined to determine if it has an impact upon the decision to work from home. The first set of variables relates to bus availability. This variable is measured in the number of bus stops per 1,000 in each are examined. The rail availability variable takes a binary value in relation to if rail was available or not. The final variable that is related to the area that the individual lives in is broadband Internet coverage. As the POWCAR data does not contain information if a household has a broadband Internet connection data was used that has the average number of households in area with a broadband connection. This data is related to the electoral district and is the percentage of households in that area with a broadband connection, as seen in Table 3 this falls into three categories.

Table 3 Description of variables examined 


\begin{tabular}{|c|c|}
\hline-28 to -8 & $=1$ if Deprivation score: -28 to -8 \\
\hline-7 to 0 & $=1$ if Deprivation score: -7 to 0 \\
\hline 1 to 3 & $=1$ if Deprivation score: 1 to 3 \\
\hline Greater than 3 & $\begin{array}{l}\text { Reference category = Deprivation } \\
\text { score Greater than } 3\end{array}$ \\
\hline \multicolumn{2}{|l|}{ Bus stops per 1,000 people } \\
\hline $0-4$ stops & $\begin{array}{l}\text { = } 1 \text { if bus stops per } 1,000 \text { people: } \\
0-4 \text { stops }\end{array}$ \\
\hline 5-10 stops & $\begin{array}{l}=1 \text { if bus stops per } 1,000 \text { people: } \\
5-10 \text { stops }\end{array}$ \\
\hline $11-15$ stops & $\begin{array}{l}=1 \text { if bus stops per } 1,000 \text { people: } \\
11-15 \text { stops }\end{array}$ \\
\hline 16 plus stops & $\begin{array}{l}\text { Reference category = bus stops } \\
\text { per } 1,000 \text { people: } 16 \text { plus stops }\end{array}$ \\
\hline \multicolumn{2}{|l|}{ Rail availability } \\
\hline Yes & $=1$ if Rail availability: Yes \\
\hline No & $\begin{array}{l}\text { Reference category = Rail } \\
\text { availability: No }\end{array}$ \\
\hline \multicolumn{2}{|l|}{ Broadband internet coverage } \\
\hline $0-50 \%$ of households have broadband connections & $\begin{array}{l}\text { = } 1 \text { if Broadband internet coverage: } \\
0-50 \% \text { of households }\end{array}$ \\
\hline $51-75 \%$ of households have broadband connections & $\begin{array}{l}=1 \text { if Broadband internet coverage: } \\
51-75 \% \text { of households }\end{array}$ \\
\hline Over $76 \%$ of households have broadband connections & $\begin{array}{l}\text { Reference category = Broadband } \\
\text { internet coverage: Over } 76 \% \text { of } \\
\text { households }\end{array}$ \\
\hline \multicolumn{2}{|l|}{ POWSCAR Variables } \\
\hline \multicolumn{2}{|l|}{ Age } \\
\hline $15-24$ & $=1$ if Age: $15-24$ \\
\hline $25-34$ & $=1$ if Age: $25-34$ \\
\hline $35-44$ & $=1$ if Age: $35-44$ \\
\hline $45-54$ & $=1$ if Age: $15-24$ \\
\hline $55-64$ & $=1$ if Age: $15-24$ \\
\hline $65+$ & Reference category $=$ Age: $65+$ \\
\hline \multicolumn{2}{|l|}{ Household Structure } \\
\hline Group 1: Single Person & $=1$ if Household Structure: Group 1 \\
\hline $\begin{array}{l}\text { Group 2: Lone parent: with at least one resident child } \\
\text { aged } 19 \text { or under }\end{array}$ & $=1$ if Household Structure: Group 2 \\
\hline $\begin{array}{l}\text { Group 3: Lone parent: with resident children but none } \\
\text { aged under } 19\end{array}$ & $=1$ if Household Structure: Group 3 \\
\hline $\begin{array}{l}\text { Group 4: Couple: with at least one resident child aged } \\
19 \text { or under }\end{array}$ & $=1$ if Household Structure: Group 4 \\
\hline $\begin{array}{l}\text { Group 5: Couple with resident children but none aged } \\
19 \text { or under }\end{array}$ & $=1$ if Household Structure: Group 5 \\
\hline Group 6: Couple with no resident children & $=1$ if Household Structure: Group 6 \\
\hline Group 7: Other Households & $\begin{array}{l}\text { Reference category = Household } \\
\text { Structure: Group } 7\end{array}$ \\
\hline \multicolumn{2}{|l|}{ Residential Density } \\
\hline Less than 2,000 people & $\begin{array}{l}=1 \text { if Residential density: Less than } \\
2,000 \text { people }\end{array}$ \\
\hline 2,001 to 50,000 people & $\begin{array}{l}=1 \text { if Residential density: } 2,001 \text { to } \\
50,000 \text { people }\end{array}$ \\
\hline
\end{tabular}




\begin{tabular}{|l|l|}
\hline Over 50,000 people & $\begin{array}{l}\text { Reference category = Residential } \\
\text { density: Over 50,000 people }\end{array}$ \\
\hline Car available & \\
\hline One & $=1$ if Car available: One \\
\hline Two & $=1$ if Car available: Two \\
\hline Three or more & $=1$ if Car available: Three or more \\
\hline No car & $\begin{array}{l}\text { Reference category = Car } \\
\text { available: No car }\end{array}$ \\
\hline & \\
\hline Industrial Group & $=1$ if Industrial Group: Group 1 \\
\hline Group 1: Not stated & $=1$ if Industrial Group: Group 2 \\
\hline Group 2: Agriculture, forestry and fishing & $=1$ if Industrial Group: Group 3 \\
\hline $\begin{array}{l}\text { Group 3: Manufacturing, mining and quarrying, } \\
\text { Electricity, Gas, Water supply and Waste Management }\end{array}$ & $=1$ if Industrial Group: Group 4 \\
\hline Group 4: Construction & $=1$ if Industrial Group: Group 5 \\
\hline $\begin{array}{l}\text { Group 5: Wholesale, Retail Trade, Transportation and } \\
\text { Storage, Accommodation and Food Service Activities }\end{array}$ & $=1$ if Industrial Group: Group 6 \\
\hline $\begin{array}{l}\text { Group 6: Information and Communication, Financial, } \\
\text { Real Estate, Professional, administration and support } \\
\text { service activities }\end{array}$ & \\
\hline $\begin{array}{l}\text { Group 7: Public Administration and Defense; } \\
\text { Compulsory Social Security }\end{array}$ & $=1$ if Industrial Group: Group 7 \\
\hline $\begin{array}{l}\text { Group 8: Education, Human Health and Social Work } \\
\text { Activities }\end{array}$ & $=1$ if Industrial Group: Group 8 \\
\hline \begin{tabular}{l} 
Group 9: Other Service Activities \\
\hline Highest level third level education
\end{tabular} & $\begin{array}{l}\text { Reference category = Industrial } \\
\text { Group: Group 9 }\end{array}$ \\
\hline Education level & \\
\hline Highest level secondary level education & $\begin{array}{l}\text { secondary level education } \\
\text { secolion }\end{array}$ \\
\hline & $\begin{array}{l}\text { Reference category = Education } \\
\text { level: Highest level third level } \\
\text { education }\end{array}$ \\
\hline
\end{tabular}

\subsection{Modelling Approach}

This section of the paper describes the modelling approach used to examine the POWSCAR data and the supplemental data to determine what factors impact upon the probability of an individual living in an area with a high of individuals working from home. A multinomial logit regression model was used in this research to estimate these relationships. Three levels of working from home are examined in the model, the first level was areas with less than $2 \%$ of individuals working from home, the second level includes areas with 2-3\% of individuals working from home and finally the third level represents areas with $3 \%$ or more of individuals working from home. The multinomial logit model takes the following functional form:

Equation 1

$$
\operatorname{logit}(p)=\log \frac{p}{1-p}=a+\beta I+\gamma H+e
$$


where $p$ is the probability that event $Y$ occurs (in the case of this study it is the probability that someone lives in an area with a higher percentage of individuals working from home). $\beta I$ is the set of individual specific characteristics (these include education, age and occupation etc.), $\mathrm{rH}$ is the set of household specific characteristics (these include public transport availability, broadband Internet coverage and household structure etc.). The results estimated from these models are presented in Table 4.

\section{Results and analysis}

Table 4 presents the results of the multinomial logistic regression model estimated to explain what factors influence increased working from home. The variables examined and the modelling process is described in section 3.1. The first set of variables examines the rates of deprivation and how it impacts upon the areas with varying rates of working from home. The results show that those individuals living in more affluent areas (those areas with a deprivation index score of 3 or more) are more likely to work from home compared to those living in more deprived areas. A comparison between those living in areas with $2 \%$ working from home and those living in areas with $3 \%$ or more working from home shows that those living in the second category are more likely to live in an affluent area compared to those in the first category. The next set of variables examines the impacts that access to public transport has upon the likelihood of working from home. The results show that those living in areas with $3 \%$ or more working from home are less likely to have good public transport access as they are more likely to have $0-4$ bus stops per 1,000 people and not likely to have rail available in their area. In contrast those living in an area with $2 \%$ of individuals working from home are likely to have good bus availability and a rail option available.

The next set of variables examined relates to the age profile of those in the different areas and the household structure. The results for the age profiles show that those in areas with high levels of individuals working from home are likely to be in the 45-54 and 55-64 age categories. Household structure is examined in the model to determine what impacts it has upon working from home, the results show that single people and those couples with children under the age 19 were most likely to live in an area with the highest percentage of individuals working from home. The results for the residential density variables shows that areas with the highest levels of working from home were most likely to have low population densities.

The results for the numbers of cars available show that those living in the areas with the highest proportions of those working from home were shown to be most likely to have multiple cars per household. The results for the industrial group show, as one would expect, that those in Group 2 (Agriculture, forestry and fishing) were most likely to live in an area with a high percentage of individuals working from home. The results for industrial group also show that those working in Group 6 (Information and Communication, Financial, Real Estate, Professional, administration and support service activities) were also most likely to live in an area with a high percentage of individuals working from home. The variables that measure broadband Internet coverage rates show, as one might expect, individuals living in areas with higher percentages of those working from home were least likely to live in areas with lower broadband Internet coverage. Finally the education variables show that those with higher levels of education were shown to be most likely to live in areas with higher levels of people working from home. 
Table 4 Results of the multinomial logit model

\begin{tabular}{|c|c|c|c|c|}
\hline \multirow[t]{2}{*}{ Variable } & \multicolumn{2}{|l|}{$2 \%$ WFH } & \multicolumn{2}{|l|}{$\begin{array}{l}3 \% \text { or more } \\
\text { WFH }\end{array}$} \\
\hline & Coefficient & S.E. & Coefficient & S.E. \\
\hline \multicolumn{5}{|l|}{ Deprivation index } \\
\hline Greater than 3 & $4.659 * *$ & .016 & $5.217 * *$ & .018 \\
\hline 1 to 3 & $2.521 * *$ & .015 & $2.785 * *$ & .016 \\
\hline-7 to 0 & $2.264 * *$ & .012 & $1.565 * *$ & .013 \\
\hline-28 to -8 & $0 \mathrm{~b}$ &. & $0 \mathrm{~b}$ &. \\
\hline \multicolumn{5}{|l|}{ Bus stops per 1,000 } \\
\hline $0-4$ & $1.431 * *$ & .014 & $0.161 * *$ & .014 \\
\hline $5-10$ & $0.088 * *$ & .013 & $-1.039 * *$ & .013 \\
\hline $11-15$ & $1.015^{* *}$ & .013 & $-0.673^{* *}$ & .014 \\
\hline 16 plus & $\mathrm{Ob}$ &. & $\mathrm{Ob}$ & to \\
\hline \multicolumn{5}{|l|}{ Rail available } \\
\hline Yes & $0.448 * *$ & .008 & $-0.228 * *$ & .01 \\
\hline No & $\mathrm{Ob}$ &. & $\mathrm{Ob}$ &. \\
\hline \multicolumn{5}{|l|}{ Age } \\
\hline $15-24$ & $-0.698 * *$ & .037 & $-1.11 * *$ & .04 \\
\hline $25-34$ & $-0.723 * *$ & .035 & $-1.114 * *$ & .037 \\
\hline $35-44$ & $-0.532 *$ & .035 & $-0.769 * *$ & .038 \\
\hline $45-54$ & $0.393 * *$ & .035 & $0.616^{* *}$ & .038 \\
\hline $55-64$ & $0.2 * *$ & .036 & $0.324 * *$ & .038 \\
\hline $65+$ & $\mathrm{Ob}$ & . & $\mathrm{Ob}$ & . \\
\hline \multicolumn{5}{|l|}{ Household Structure } \\
\hline Single Person & $0.457 * *$ & .017 & $0.873 * *$ & .021 \\
\hline Lone parent: with at least one resident child aged 19 or under & $0.403 * *$ & .021 & $0.735 * *$ & .025 \\
\hline Lone parent: with resident children but none aged under 19 & $0.514 * *$ & .022 & $0.767 * *$ & .026 \\
\hline Couple: with at least one resident child aged 19 or under & $0.411 * *$ & .012 & $0.792 * *$ & .015 \\
\hline Couple with resident children but none aged 19 or under & $0.435 * *$ & .016 & $0.684^{*}$ & .019 \\
\hline Couple with no resident children & $0.322 * *$ & .013 & $0.618 * *$ & .016 \\
\hline Other Households & $\mathrm{Ob}$ &. & $\mathrm{Ob}$ &. \\
\hline \multicolumn{5}{|l|}{ Residential Density } \\
\hline Less than 2,000 people & $0.397 * *$ & .012 & $1.182 * *$ & .013 \\
\hline 2,001 to 50,000 people & $0.513 * *$ & .011 & $1.112 * *$ & .012 \\
\hline Over 50,000 people & $\mathrm{Ob}$ &. & $0 \mathrm{~b}$ & . \\
\hline \multicolumn{5}{|l|}{ Car available } \\
\hline One & $0.893 * *$ & .015 & $1.16^{* *}$ & .019 \\
\hline Two & $1.308 * *$ & .016 & $1.944 * *$ & .02 \\
\hline Three or more & $1.481 * *$ & .018 & $2.37 * *$ & .023 \\
\hline No car & $\mathrm{Ob}$ &. & Ob &. \\
\hline \multicolumn{5}{|l|}{ Industrial Group } \\
\hline Group 1: Not stated & $-0.082 *$ & .048 & $-0.119 * *$ & .055 \\
\hline Group 2: Agriculture, forestry and fishing & $0.529 * *$ & .055 & $1.199 * *$ & .052 \\
\hline $\begin{array}{l}\text { Group 3: Manufacturing, mining and quarrying, Electricity, Gas, Water supply and } \\
\text { Waste Management }\end{array}$ & $-0.016^{* *}$ & .021 & $-0.072 * *$ & .025 \\
\hline Group 4: Construction & $0.002 * *$ & .03 & $0.043 * *$ & .034 \\
\hline $\begin{array}{l}\text { Group 5: Wholesale, Retail Trade, Transportation and Storage, Accommodation } \\
\text { and Food Service Activities }\end{array}$ & $-0.142 * *$ & .019 & $-0.266^{* *}$ & .022 \\
\hline $\begin{array}{l}\text { Group 6: Information and Communication, Financial, Real Estate, Professional, } \\
\text { administration and support service activities }\end{array}$ & $0.073 * *$ & .019 & $0.142 * *$ & .022 \\
\hline Group 7: Public Administration and Defense; Compulsory Social Security & $-0.009 * *$ & .022 & $-0.086^{* *}$ & .026 \\
\hline Group 8: Education, Human Health and Social Work Activities & $0.062 * *$ & .019 & $0.031 * *$ & .022 \\
\hline Group 9: Other Service Activities & $\mathrm{Ob}$ &. & $\mathrm{Ob}$ &. \\
\hline \multicolumn{5}{|l|}{ Broadband internet coverage } \\
\hline $0-50 \%$ of households have broadband connections & $-0.824 * *$ & .042 & $-3.363 * *$ & .028 \\
\hline $51-75 \%$ of households have broadband connections & $0.032 * *$ & .041 & $-1.828 * *$ & .026 \\
\hline Over $76 \%$ of households have broadband connections & Ob & . & Ob & . \\
\hline \multicolumn{5}{|l|}{ Education level } \\
\hline Highest level secondary level education & -0.156 & .008 & -0.294 & .001 \\
\hline Highest level third level education & Ob & & Ob & . \\
\hline $\mathrm{N}$ & \multicolumn{4}{|l|}{768,813} \\
\hline Nagelkerke R2 & .440 & & & \\
\hline
\end{tabular}




\begin{tabular}{|l|l|}
\hline Chi-squared statistic & 258269.951 \\
\hline Degrees of freedom & 66 \\
\hline-2 log likelihood & 40021.893 \\
\hline
\end{tabular}

\subsection{Commute savings for travel to work}

This section of the paper examines the travel time saved and the economic benefits of working from home. In order to estimate the travel time saved it was necessary to estimate a proxy for the potential travel time for each of those currently working from home. As no travel time is recorded for those working from home it was decided to use other individuals living in the same electoral district and in the same industrial grouping as a proxy for a potential journey time. Multi-stop trips could not be taken into account as POWSCAR doesn't provide this information. To estimate this proxy travel time for those working from home the average travel time for each of the eight industrial groups was estimated across the 690 electoral districts in the GDA. It was important to estimate the average travel time by electoral district as it gives the best proxy for a travel time for those that work from home. The average travel time by electoral district and industrial grouping was then calculated and the average travel time in hours for each industrial grouping is presented in Table 5. It should be noted that this is just a proxy for travel time and is the best possible estimate for a potential travel time for those working from home.

The average travel time saved is calculated by multiplying the average travel time by the average 215 working days per year - this assumes a return trip every working day of the year. This approach is also used in McNamara and Caulfield (2011). This then gives the average travel time saving per year. Table 5 also presents the standard deviation of the travel time saving per year. The average annual travel time saving is then multiplied by the numbers of individuals in each industrial group that indicated they work from home to estimate the overall travel time saving. The results shows that those working from home have saved approximately 3.8 million hours of travel time in the GDA. The total travel time saving is then multiplied by the value of travel time in Ireland $(€ 10.98)(N R A, 2011)$ to estimate the economic benefit from working from home. The national value of travel time in Ireland was chosen as this is the value that is used to estimate the benefits and costs of other national transport projects. This value of travel time is estimates using salary levels. The results show that working from home has an economic benefit, using only travel time savings, of €42.2 million based upon 2011 travel to work data.

The purpose of this analysis was to demonstrate the potential travel time savings that can accrue from working from home. While the methods used in this section are rather crude, the intention of this analysis is not to provide a definitive economic benefit, rather an indication of the benefits.

Table 5 The economic and time benefits of working from home

\begin{tabular}{|l|l|l|l|c|}
\hline Industrial Group & $\begin{array}{l}\text { Total travel } \\
\text { time saved } \\
\text { per year } \\
\text { (hours) }\end{array}$ & $\begin{array}{l}\text { Average } \\
\text { travel time } \\
\text { saved per } \\
\text { year (hours) }\end{array}$ & $\begin{array}{l}\text { Standard } \\
\text { deviation of } \\
\text { travel time saved } \\
\text { per year (hours) }\end{array}$ & $\begin{array}{l}\text { Economic benefit } \\
\text { of travel time } \\
\text { saved per year }\end{array}$ \\
\hline $\begin{array}{l}\text { Group 1: Agriculture, forestry and } \\
\text { fishing }\end{array}$ & 309,602 & 1,022 & 733 & $€ 3,399,425$ \\
\hline $\begin{array}{l}\text { Group 2: Manufacturing, mining } \\
\text { and quarrying, Electricity, Gas, } \\
\text { Water supply and Waste }\end{array}$ & 296,089 & 712 & 682 & $€ 3,251,058$ \\
\hline
\end{tabular}




\begin{tabular}{|c|c|c|c|c|}
\hline Management & & & & \\
\hline Group 3: Construction & 168,422 & 288 & 433 & $€ 1,849,274$ \\
\hline $\begin{array}{l}\text { Group 4: Wholesale, Retail } \\
\text { Trade, Transportation and Storage, } \\
\text { Accommodation and Food Service } \\
\text { Activities }\end{array}$ & 568,907 & 1090 & 1078 & $€ 6,246,603$ \\
\hline $\begin{array}{l}\text { Group 5: Information and } \\
\text { Communication, Financial, Real } \\
\text { Estate, Professional, } \\
\text { administration and support service } \\
\text { activities }\end{array}$ & $1,689,044$ & 3211 & 3929 & $€ 18,545,700$ \\
\hline $\begin{array}{l}\text { Group 6: Public Administration } \\
\text { and Defence; Compulsory Social } \\
\text { Security }\end{array}$ & 77,498 & 395 & 301 & $€ 850,925$ \\
\hline $\begin{array}{l}\text { Group 7: Education, Human } \\
\text { Health and Social Work Activities }\end{array}$ & 401,061 & 928 & 1011 & $€ 4,403,651$ \\
\hline Group 8: Other Service Activities & 338,416 & 760 & 682 & $€ 3,715,811$ \\
\hline Total & $3,849,039$ & & & $€ 42,262,447$ \\
\hline
\end{tabular}

\section{Conclusions}

The findings presented in this paper show the potential of working from home as a sustainable transport policy. The GDA is typical of many urban areas around the world and the findings of this study show the potential benefits of working from home in terms of travel time saved and the value of travel time saved. The factors that influence the potential to work from home found in this study mirror those found in many other international studies. However, this study does add to the body of knowledge internationally as it examines the impacts that access to public transport and deprivation have upon the likelihood of working from home. The findings in relation to these variables suggest that those living in more affluent areas and those with poor public transport connectivity are more likely to work from home. While the results from this case study show the levels of working from home and the factors that impact upon them, further research is required to gain a better understanding of these patterns. This further investigation would require survey work and not wholly rely on census data.

\section{Appendix A: Composition of Deprivation Index}

This section of the paper describes the variables used in the calculation of the deprivation index. For further information on this index pleases see Haase and 
Pratschke (2012). The deprivation index is comprised variables that can be classified into three categories and are shown in the graph below.

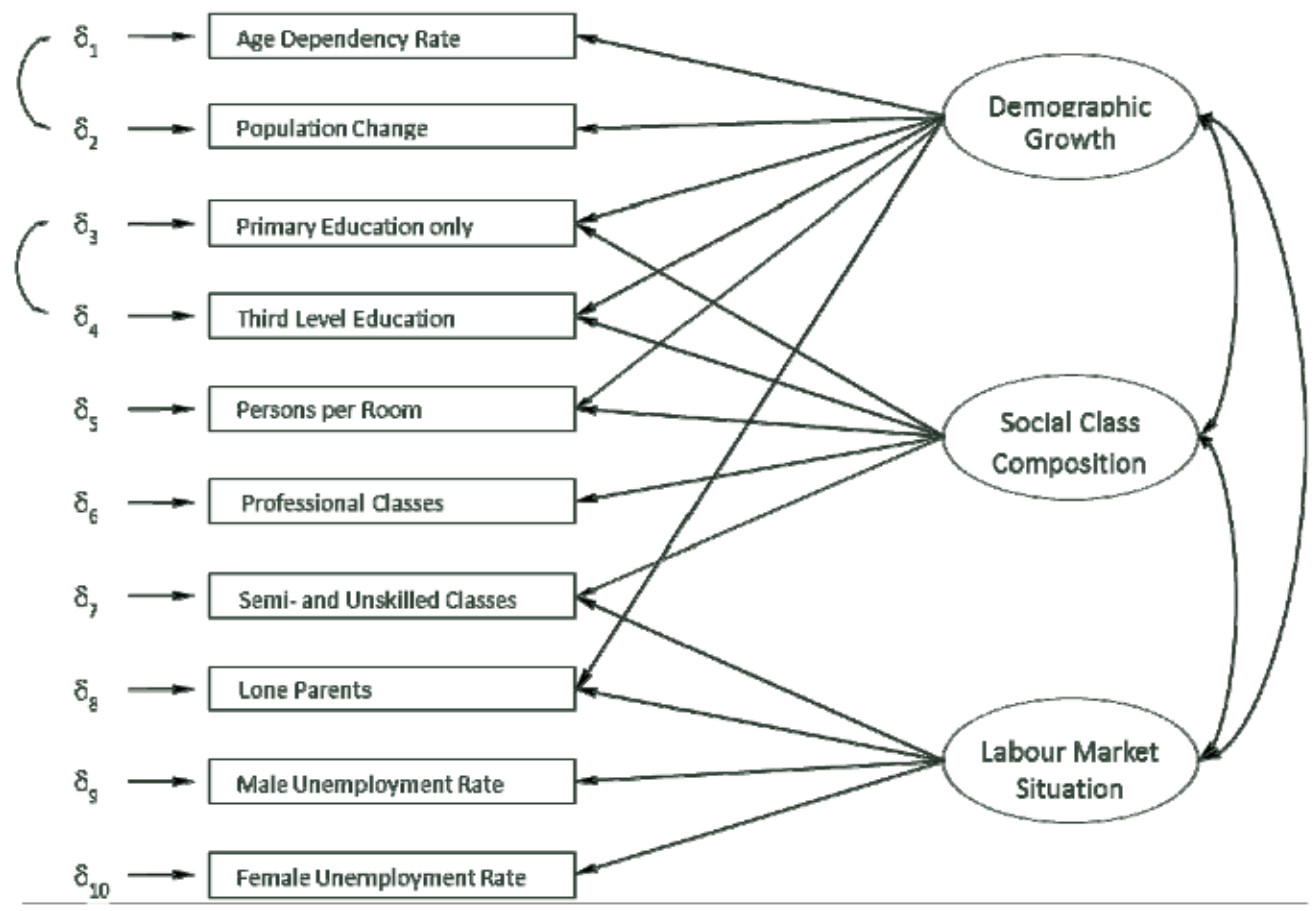

Figure 3 Deprivation Index: Source (Haase and Pratschke, 2012)

\section{References:}


Alexander, B., Dijst, M. Professional workers @ work: importance of work activities for electronic and face-to-face communications in the Netherlands. Transportation, 2012, 39, pp 919-940

Alexander, B., Dijst, M., Ettema, D. Working from 9 to 6? An analysis of in-home and out-of-home working schedules. Transportation, 2010, 37, pp 505-523

Calderwood, E., Freathy, P. Consumer mobility in the Scottish isles: The impact of the Internet adoption upon retail travel patterns. Transportation Research Part A. 2014, 59, pp 192-203.

Caulfield., B., Re-cycling a city - examining the growth of cycling in Dublin, Transportation Research Part A: Policy and Practice, 61, 2014, p216 - 226

Caulfield, B., Bailey, D., Mullarkey, S., Using Data Envelopment Analysis as a public transport project appraisal tool, Transport Policy, 29, 2013, p74 - 85

Caulfield, B. An examination of the factors that impact upon multiple vehicle ownership: The case of Dublin, Ireland, Transport Policy, 19, 2012, p132 - 138

Caulfield, B., Ahern, A., The Green Fields of Ireland: The Legacy of Dublin's Housing Boom and the Impact on Commuting, Case Studies on Transport Policy, 2, (1), 2014, p20 - 27

Central Statistics Office. Census of Ireland, 2011, Dublin

Central Statistics Office, Accessed on line: 29/1/2015http://www.cso.ie/en/statistics/labourmarket/principalstatistics/seasonallyad justedstandardisedunemploymentratessur/

Choo, S., Mokhtarian, P.L., Salomon, I. Does telecommuting reduce vehicle-miles travelled? An aggregate time series analysis for the U.S. Transportation, 2005, 32, pp 37-64.

Department of Transport. Smarter Travel: A New Transport Policy for Ireland 20092020. DoT, Dublin.

Fu, M., Kelly, A., Clinch, P., King, F. Environmental policy implications of working from home: Modelling the impacts of land-use, infrastructure and socio-demographics. Energy Policy, 2012, 47, pp 416-423

Golob, T, F., Regan, A, C. Impacts of information technology on personal travel and commercial vehicle operations: research challenges and opportunities. Transportation Research Part C, 2001, 9, pp 87-121.

Haase, T., Pratschke, J. The 2011 Pobal HP Deprivation Index for Small Areas. 2012. Dublin.

Mannering, J.S., Mokhtarian, P.L. Modelling the choice of telecommuting frequency in California: An exploratory analysis. Technological Forecasting and Social Change, Volume 49, Issue 1, May 1995, Pages 49-73 
McNamara, D., Caulfield, B. , Determining the welfare effects of introducing a capand-share scheme on rural commuters, Transportation Research Part D: Transport and Environment, 16, 2011, p547 - 553

Mokhtarian, P., Varma, K. The trade-off between trips and distance travelled in analysing the emissions impacts of centre-based telecommuting. Transportation Research Part D: Transport and the Environment, 3, 6, 1988, pp 419-428

National Roads Authority, Project Appraisal Guidelines, 2011, NRA, Dublin

Nelson, P., Safirova, E., Walls, M. Telecommuting and environmental policy:

Lessons from the ecommute program Transportation Research Part D: Transport and Environment, Volume 12, Issue 3, May 2007, Pages 195-207

Noland, R. B., Cowart, W.A., Fulton, L.M. Travel demand policies for saving oil during a supply emergency. Energy Policy, 2006, 34, pp 2994-3005.

Olszewski, P., Mokhtarian, P. Telecommuting frequency and impacts for the State of California employees Technological Forecasting and Social Change, Volume 45, Issue 3, March 1994, Pages 275-286

Henderson, D., Mokhtarian, P. Impacts of centre-based telecommuting on travel and emissions: Analysis of the Puget Sound Demonstration Project. Transportation Research Part D: Transport and Environment, 1, 1, 1996, pp 29-45

Ren, F., Kwan, M. The impact of the Internet on human activity-travel patterns: analysis of gender differences using multi-group structural equation models. Journal of Transport Geography, 2009, 17, pp 440-450.

Schwanen, T., Banister, D., Anable, J. Scientific research about climate change mitigation in transport: A critical review. Transportation Research Part A: Policy and Practice, 45, 10, 2011, pp 993-1006 